\title{
REKONSTRUKSI BIROKRASI PEMERINTAH DAERAH PENGUJIAN KENDARAAN BERMOTOR BERBASIS NILAI KEADILAN (Study tentang Birokrasi Pengujian Kendaraan Bermotor pada Dinas Perhubungan Kabupaten/Kota di Jawa Tengah)
}

\author{
Imam Sudrajat \\ PNS Dinas Perhubungan Propinsi Jawa Tengah \\ imamsudrajat00@yahoo.com
}

\begin{abstract}
Implementation of Bureaucracy in testing at the Motor Vehicle Department of Transportation District/town in Central Java is not based on the value of justice due to the Problem Statement that occur in relation to services and feasibility testing of motor vehicles is not only a service procedure, but the commitment of employees to carry out services and feasibility testing of motor vehicles less reflect fairness and transfaransi. Servicing and testing the feasibility of a motor vehicle cannot fully satisfy the community because people's understanding of the feasibility of testing services of motor vehicles, apparently not all of them know and understand procedurally. Motor Vehicle Testing privatization, improve the effectiveness of supervision, resource efficiency and diversion of fuel, vehicle age restrictions and determination of progressive taxation of vehicles).
\end{abstract}

Keyword: Bureaucracy Reconstruction, Highway Users, Value of Justice, Motor Vehicle Inspection

\begin{abstract}
Abstraksi
Pelaksanaan Birokrasi dalam pengujian Kendaraan Bermotor pada Dinas Perhubungan Kabupaten/Kota di Jawa Tengah belum berdasarkan nilai keadilan dikarenakan adanya Problem Statement yang terjadi dalam kaitannya dengan pelayanan dan pengujian kelaikan kendaraan bermotor tidak hanya menyangkut prosedur pelayanan, akan tetapi komitmen pegawai dalam melaksanakan pelayanan dan pengujian kelaikan kendaraan bermotor kurang mencerminkan keadilan dan transparansi. Pelayanan dan pengujian kelaikan kendaraan bermotor belum sepenuhnya dapat memuaskan masyarakat karena pemahaman masyarakat terhadap pelayanan pengujian kelaikan kendaraan bermotor, nampaknya belum semuanya mengerti dan memahami secara prosedural. swastanisasi Pengujian Kendaraan Bermotor, Pengefektifan Pengawasan, Efisiensi dan pengalihan sumber bahan bakar minyak, pembatasan usia kendaraan dan penetapan pajak progresif kendaraan)
\end{abstract}

Kata Kunci: Rekonstruksi Birokrasi, Nilai Keadilan, Pengujian Kendaraan Bermotor

\section{A. PENDAHULUAN}

Reformasi birokrasi pada hakikatnya merupakan upaya untuk melakukan pembaharuan dan perubahan mendasar terhadap sistem penyelenggaraan pemerintahan terutama menyangkut aspek-aspek kelembagaan (organisasi), ketatalaksanaan (business process) dan sumber daya manusia aparatur.

Berbagai permasalahan atau hambatan yang mengakibatkan sistem penyelenggaraan pemerintahan tidak akan berjalan dengan baik, harus ditata ulang atau diperbaharui. Reformasi birokrasi dilaksanakan dalam rangka mewujudkan tata kelola pemerintahan yang baik (good governance).

Dengan kata lain, reformasi birokrasi adalah langkah strategis untuk membangun aparatur negara agar lebih berdaya guna dan berhasil guna dalam mengemban tugas umum pemerintahan dan pembangunan nasional. Selain itu dengan sangat pesatnya kemajuan ilmu pengetahuan, teknologi informasi dan komunikasi serta 
perubahan lingkungan strategis, menuntut birokrasi pemerintahan untuk direformasi dan disesuaikan dengan dinamika tuntutan masyarakat. Oleh karena itu harus segera diambil langkahlangkah yang bersifat mendasar, komprehensif, dan sistematik, sehingga tujuan dan sasaran yang telah ditetapkan dapat dicapai dengan efektif dan efisien. Dalam konteks ini reformasi merupakan proses pembaharuan yang dilakukan secara bertahap dan berkelanjutan, sehingga tidak termasuk upaya dan/atau tindakan yang bersifat radikal dan revolusioner.

Pada intinya latar belakang reformasi ini adalah sebagai berikut:

1. Praktek Korupsi, Kolusi, dan Nepotisme $(\mathrm{KKN})$ masih berlangsung hingga saat ini.

2. Tingkat kualitas pelayanan publik yang belum mampu memenuhi harapan publik.

3. Tingkat efisiensi, efektifitas, dan produktivitas yang belum optimal dari birokrasi pemerintahan.

4. Tingkat transparansi dan akuntabilitas birokrasi pemerintahan yang masih rendah.

5. Tingkat disiplin dan etos kerja pegawai masih rendah. ${ }^{1}$

Dalam kehidupan sebuah negara yang merdeka dan berdaulat, birokrasi mempunyai peranan dan fungsi penting dalam menjalankan kehidupan di suatu negara.Namun, besarnya pengaruh kekuasaan dan politik mengakibatkan birokrasi tidak profesional atau mandul. Birokrasi dengan kultur yang dibangunnya, cenderung lebih sibuk melayani penguasa daripada menjalankan fungsi utamanya sebagai pelayan masyarakat. Misalnya, dalam bidang pelayanan publik, upaya yang telah dilakukan dengan menetapkan standar pelayanan publik, dengan harapan pelayanan yang cepat, tepat, murah, dan transparan belum dapat terwujud.Upaya tersebut belum banyak dinikmati masyarakat, dikarenakan pelaksanaan sistem dan prosedur pelayanannya kurang efektif, efisien.Berbelitbelit, lamban, tidak merespon kepentingan pelanggan/masyarakat yang ditimpakan kepada birokrasi. Semua ini merupakan cerminan

1 Sugondo BK, Media KORPRI, Edisi Desember 2012, hlm.5 bahwa kondisi birokrasi dewasa ini dalam memberikan pelayanan kepada masyarakat, masih belum sesuai dengan harapan dan keinginan masyarakat.

Ketidapuasan terhadap kinerja pelayanan publik, dapat dilihat dari keengganan masyarakat berhubungan dengan birokrasi pemerintah atau dengan adanya kesan untuk sejauh mungkin menghindari birokrasi pemerintah. Fenomena kurang responsif, kurang informatif, kurang koordinasi, tidak mau mendengar keluhan/saran/ aspirasi masyarakat inefisiensi dan birokratis, merupakan kondisi pelayanan publik yang dirasakan oleh masyarakat selama ini. Hal ini disebabkan karena masih banyaknya peran Kementrian/Lembaga pemerintah tumpang tindih, yang dirasakan masih sentralistik, kurangnya infrastruktur, masih menguatnya budaya dilayani bukan melayani, transparansi biaya dan prosedur pelayanan yang belum jelas, serta sistem insentif/ penghargaan dan sanksi belum maksimal.

Reformasi Birokrasi telah melahirkan berbagai perubahan dalam sistem penyelenggaraan pemerintahan salah satunya adalah perubahan sistem Pemerintahan Daerah sejak diberlakukannya Undang-Undang Nomor 22 Tahun 1999 dan Undang-Undang Nomor 25 Tahun 1999, yang kemudian disempurnakan dengan Undang-Undang Nomor 32 Tahun 2004 tentang Pemerintahan Daerah dan Undang-Undang Nomor 33 Tahun 2004 tentang Perimbangan Keuangan Pusat dan Daerah. Kedua undangundang ini telah menggeser paradigma pelayanan, dari yang bersifat sentralistis ke desentralisasi dan mendekatkan pelayanan secara langsung kepada masyarakat.

Selain itu juga deregulasi peraturan perundangundangan, pemanfaatan dan pengembangan e-Government, di bidang pelayanan publik (standar pelayanan minimal, perbaikan sistem dan mekanisme, modernisasi tata laksana, sistem penghargaan dan sanksi), di bidang kepegawaian (sistem rekruitmen, diklat berbasis kompetensi, dan penyelesaian status pegawai honorer, pegawai harian lepas, dan pegawai tidak tetap), dan bidang kelembagaan (penataan organisasi dan kelembagaan pemerintah pusat dan daerah).

Berdasarkan peraturan perundang-undangan yang berlaku, yaitu Undang-Undang Nomor 22 
Tahun 2009 tentang Lalu Lintas dan Angkutan Jalan, Peraturan Pemerintah Nomor 55 Tahun 2012 tentang Kendaraan serta Peraturan Gubernur Nomor 75 Tahun 2008 tentang Penjabaran Tugas Pokok, Fungsi dan Tata Kerja Dinas Perhubungan, Komunikasi dan Informatika Provinsi Jawa Tengah bahwa kewenangan penyelenggaraan Pengujian Kendaraan Bermotor adalah Pemerintah Kabupaten atau Kota, sedangkan Pemerintah Provinsi mempunyai peran sebagai pembina.

Setiap kendaraan bermotor yang dioperasikan di jalan berpotensi untuk mencelakai orang di jalan dan mencemari lingkungan, dengan demikian setiap kendaraan bermotor yang dioperasikan di jalan harus memenuhi persyaratan teknis dan laik jalan. Untuk memastikan bahwa kendaraan bermotor telah memenuhi persyaratan teknis harus dilakukan pengujian.

Kendaraan bermotor juga telah lama menjadi salah satu sumber pencemar udara di banyak kota besar dunia. Gas-gas beracun dari jutaan knalpot setiap harinya menimbulkan masalah serius di banyak negara. Tak terkecuali Indonesia, yang jutaan kendaraannya berbahan bakar bensin sehingga menjadi sumber pencemar udara terbesar di beberapa kota melebihi industri dan rumah tangga. Transportasi merupakan salah satu kebutuhan penunjang dalam kehidupan manusia. Dalam memenuhi berbagai kebutuhan hidup, manusia dan barang selalu bergerak, berpindah dari satu tempat ke tempat lain. Pemindahan manusia dan barang dimaksudkan membutuhkan sarana transportasi yang selamat, aman, nyaman, tertib dan lancar, tepat waktu serta dengan biaya terjangkau.

Keinginan untuk tiba di tempat yang tepat waktu, dengan aman dan selamat sering berubah menjadi malapetaka yaitu terjadinya kecelakaan yang dapat mengakibatkan orang mengalami luka, meninggal dunia atau kerugian material. Pada dekade terakhir ini diberbagai negara maju berhasil menurunkan angka kecelakaan lalu lintas. Tetapi di negara-negara berkembang termasuk Indonesia belum berhasil menekan angka kecelakaan lalu lintas. Penurunan angka kecelakaan transportasi yang mengakibatkan gangguan keselamatan dengan risiko kematian, luka bagi penumpang dan kerusakan, kehilangan barang dengan kerugian material bagi publik merupakan tanggung jawab pemerintah.

Salah satu faktor penyebab kecelakaan lalu lintas adalah terkait dengan kondisi kendaraan. Meskipun kejadian kecelakaan lalu lintas yang disebabkan oleh faktor kendaraan prosentasenya hanya sekitar $8 \%-12 \%$, namun kecelakaan tersebut sering berakibat fatal (adanya korban meninggal dunia). Kondisi kelaikan kendaraan bermotor memegang peranan yang sangat penting atas terjadi atau tidaknya suatu kecelakaan lalu lintas.

Kecelakaan lalu lintas adalah salah satu permasalahan sosial terbesar di dunia khususnya di negara berkembang. Bahkan menurut WHO, kecelakaan lalu lintas merupakan salah satu penyebab kematian utama di dunia dan diprediksikan akan menjadi peringkat ke-5 di tahun 2030 jika tidak segera diatasi.

Tingkat kecelakaan negara berkembang dapat mencapai 20 kali lebih tinggi dari negara maju. Menurut Asian Development Bank (ADB), sebagian besar dari Negara ini pertumbuhan tingkat kecelakaannya sangat pesat. Di Jawa Tengah pada tahun 2012 dilaporkan terjadi 21.660 kejadian kecelakaan dengan korban meninggal dunia sejumlah 3.398 orang meninggal atau satu hari meninggal di jalan rata-rata sebanyak 9 orang, 3.611 orang luka berat dan 27.783 orang luka ringan akibat kecelakaan, serta kerugian materiil sebesar 22.7 miliar rupiah. ${ }^{2}$

Usia korban kecelakaan adalah remaja usia 15-20 tahun, merupakan korban paling yang paling banyak terlibat kecelakaan. Statistik menunjukkan pada kebanyakan negara berkembang, pejalan kaki adalah pengguna jalan yang paling rentan menjadi korban kecelakaan. Di Jawa Tengah pejalan kaki memiliki rasio meninggal dan luka lebih besar $50 \%$ daripada pengemudi ataupun penumpang kendaraan, apabila kendaraan bermotor menabrak pejalan kaki.

Berbicara masalah kelaikan kendaraan tidak terlepas dari peran dan fungsi pengujian kendaraan bermotor. Sungguh sangat memprihatinkan bahwa kinerja pengujian kendaraan bermotor di Indonesia dinilai masih sangat buruk. Berdasarkan hasil penelitian yang dilakukan oleh Bank Pembangunan Asia (ADB) tahun 2010 kinerja kelaikan kendaraan bermotor di 2 Sumber DitlantasPoldaJateng 
Indonesia menempati peringkat 10 di antara 10 negara di Asean. ${ }^{3}$

Sehubungan dengan hal tersebut, maka pengujian kendaraan bermotorpenumpang kendaraan umum adalah merupakan bagian dari keselamatan(perlindungan), baik terhadap penumpang maupun pelaku usaha/ penyelenggaraangkutan.Pelaksanaan UndangUndang Nomor 22 Tahun 2009 tentang Lalu Lintasdan Angkutan Jalan, khusus dalam menjalankan pengujian kendaraan bermotorpenumpang kendaraan umum oleh Dinas Perhubungan, merupakan langkah preventif untuk menghindari kecelakaan akibat kendaraan yang tidak layak. Tetapi pada kenyataannya bahwa masih cukup banyak kendaraan penumpang kendaraan umum yang telah lulus pengujian, masih bisa terjadi kecelakaan.

Berdasarkan uraian dalam latar belakang masalah tersebut di atas, maka permasalahan dalam penelitian ini dapat dirumuskan sebagai berikut:

1. Faktor-faktor apakah yang berpengaruh terhadap regulasi Pemerintah Daerah tentang Pengujian Kendaraan Bermotor yang belum berbasis keadilan kaitannya dengan keselamatan pengguna jalan raya?

2. Mengapa pelaksanaan pengujian Kendaraan Bermotor oleh Dinas Perhubungan Kabupaten/Kota di Jawa Tengah belum berbasis nilai keadilan?

3. Bagaimana Rekonstruksi Pelayanan Pengujian Kendaraan Bermotor oleh Dinas Perhubungan Kabupaten atau Kota di Jawa Tengah yang berbasis nilai keadilan?

\section{B. METODE PENELITIAN}

Penelitian Ini berlandaskan paradigmatic hermeneutik yang dilandasi oleh pemahaman "filsafat dan paradigma hermeneutic, dengan menggunakan metode yuridis sosiologis (Socio Legal Research). Penelitian terhadap Peraturan perundang-undangan yang berlaku, konsep dan teori hukum dilakukan di Perpustakaanperpustakaan.

3 Sumber DISHUBKOMINFO Provinsi Jawa Tengah
C. HASIL PENELITIAN DAN PEMBAHASAN

1. Faktor-faktor yang Berpengaruh Terhadap Regulasi Pemerintah Daerah tentang Pengujian Kendaraan Bermotor yang Belum Berbasis Nilai Keadilan dalam Keselamatan Pengguna Jalan Raya

Faktor-faktor yang berpengaruh terhadap regulasi pemerintah daerah tentang pengujian kendaraan bermotor yang belum berbasis nilai keadilan, adalah:

a. Adanya besaran Retribusi sebagaimana terdapat di Peraturan Daerah Dinas Perhubungan Kabupaten Semarang,Kabupaten Blora,Kabupaten Cilacap dan Kabupaten Blora memberikan penjelasan bahwa Pemerintah Daerah lebih mengedepankan adanya pemasukan bagi pendapatan Daerah.

b. Regulasi yang seharusnya dikeluarkan Pemerintah Daerah adalah lebih berfokus pada aspek kelaikan kendaraan bermotor karena sebagai tanggung jawab terhadap keselamatan pengguna jalan.

c. Belum adanya ketegasan dari Pemerintah untuk memberikan batasan terhadap batasan usia maksimal kendaraan bermotor yang diperbolehkan beroperasi di jalan raya

d. Belum tercapainya tujuan sebagaimana yang diharapkan oleh Pengujian Kendaraan Bermotor, yaitu Penyelenggaraan Pengujian Berkala Kendaraan Bermotor (PBKB) bertujuan untuk memberikan kepastian bahwa kendaraan bermotor yang dioperasikan di jalan telah memenuhi persyaratan teknis dan laik jalan serta tidak mencemari lingkungan.

e. Belum semua sasaran Pengujian Kendaraan Bermotor dapat terlaksana, meliputi:

1) Sepeda Motor;

2) Mobil penumpang;

3) Mobil penumpang umum;

4) Mobil bus; 
5) Mobil barang;

6) Kereta Tempelan;

7) Kereta Gandengan.

f. Belum dapat terlaksananya fungsi Pengujian Kendaraan Bermotor, yaitu melalui sistem pengujian berkala kendaraan bermotor, diharapkan dapat:

1) Mencegah atau memperkecil kemungkinan terjadinya :

a) Kecelakaan lalu lintas

b) Gangguan terhadap lingkungan

c) Kerusakan-kerusakan berat pada waktu pemakaian

2) Memberikan informasi kepada pemilik atau pemegang kendaran bermotor mengenai dimensi, daya angkut, tekanan sumbu terberat, kelas jalan bagi kendaraan yang bersangkutan sesuai dengan yang tercantum dalam buku uji.

3) Memberikan saran-saran perbaikan kepada bengkel-bengkel kendaraan bermotor mengenai rehabilitasi kondisi teknis kendaraan bermotor wajib uji secara berkala.

4) Menyajikan data kuantitatif mengenai potensi armada angkutan orang atau angkutan barang setempat, dalam hubungannya dengan pembinaan angkutan pada umumnya.

2. Pelaksanaan Pengujian Kendaraan Bermotor di Jawa Tengah

1. Proses Administrasi

a. Pendaftaran Uji

Secara umum proses pedaftaran uji kendaraan bermotor pada Unit Pelayanan Pengujian Kendaraan Bermotor di Jawa Tengah dilaksanakan melalui loket-loket yang telah disediakan, namun beberapa lokasi tahapan pendaftaran uji dilakukan secara langsung (tidak melalui loket). b. Pembayaran retribusi uji

Pembayaran retribusi uji dilakukan setelah proses pendaftaran selesai. Tarip retribusi pengujian kendaraan bermotor pada masing-masing daerah berbeda sesuai dengan Peraturan Daerah masing-masing.

c. Pembuatan Surat Rekomendasi (mutasi uji, numpang uji, keterangan rekomendasi)

Pembuatan surat rekomendasi dilakukan pada loket 3 , kegiatan yang dilakukan antara lain: Memberikan formulir permohonan (mutasi uji, numpang uji, keterangan rekomendasi).

d. Pembuatan Kwitansi Retribusi Uji

Menerima berkas uji yang telah dinyatakan lulus oleh penguji penyelia, memasukkan nomor pendaftaran pada komputer, mencocokkan data identitas pemohon/ pemilik kendaraan dan data identitas kendaraan pada komputer, mencetak kwitansi retribusi.

e. Pengisian Kartu induk dan Buku Uji

Pengisian identitas pemohon/ pemilik kendaraan dan identitas kendaraan pada kartu induk dan buku uji sesuai dengan surat keterangan yang ada

f. Pengesahan Buku Uji (Penandatanganan Buku Uji) Pada bagian ini, berlaku baik untuk kendaraan baru maupun mengganti buku. Hal ini dilakukan setelah mendapatkan hasil pemeriksaan teknis dari penguji, kemudian berkas diserahkan kepada penyelia untuk pengesahan buku uji. Apabila dinyatakan lulus uji, maka pemilik kendaraan akan dibuatkan plat uji dan tanda samping (stiker). Sebagai bukti 
bahwa kendaraan laik jalan maka buku uji, kartu induk dan tanda samping (stiker) ditanda tangani oleh peguji penyelia. Hasil uji berupa tanda samping (stiker) dan plat samping diberikan kepada pemilik kendaraan, sedangkan kartu induk disimpan oleh divas sebagal arsip bahwa kendaraan bermotor tersebut telah melakukan uji berkala. Proses pengujian selesai dan kendaraan dapat beroperasi di jalan. Pelaporan seperti formulir kendaraan, penetapan biaya uji, surat persetujuan numpang uji, surat keterangan mutasi kendaraan dan Berita Acara Pemeriksaan (BAP) dicantumkan pada lampiran laporan ini.

g. Penyerahan Tanda Bukti Lulus Uji

Pada bagian ini, kegiatan yang dilakukan antara lain: Menyerahkan buku uji dan plat uji kepada pemohon/pemilik kendaraan yang telah dinyatakan lulus deb penguji penyelia.

h. Pelaksanaan Uji

Pelaksanaan uji dilakukan melalui 2 tahap yaitu :

i. Checking

Checking adalah pengujian yang dilakukan secara visual (Pra Uji) untuk mengetahui tentang kondisi, fungsi kendaraan. Uji visual ini dilakukan dengan cara sebagai berikut :
a. Pemeriksaan lampu- Iampu
b. Kaca depan dan kaca jendela
c. Pandangan ke depan (Kaca Film)
d. Tanda Nomor Kendaraan Bermotor
e. Kaca Spion
f. Nomor pemeriksaan

g. Nomor chasis

h. Kondisi, ukuran, jenis pelk dan ban

i. Body kendaraan

j. Tulisan samping

k. Nomor Mesin

I. Spelling Roda Kemudi

m. Spelling Pedal

n. Alat-alat pengendali

o. Tanda peringatan bunyi atau klakson

p. Lampu-lampu indikasi

ii. Testing

Pengujian ini dilakukan dengan menggunakan semuajenis alat pengujian, namun sebagian besar Unit Pengujian hanya menggunakan beberapa alat pengujian saja dikarenakan kondisi alat yang rusak atau belum tersedianya peralatan tersebut. Beberapa sampel pelaksanaan pengujian kendaraan bermotor di Jawa Tengah adalah sebagai berikut:
a. Pengujian rem
b. Uji emisi bensin
c. Uji ketebalan asap
d. Pengukuran berat kendaraan
e. Pengukuran dimensi

\section{Rekonstruksi Pelayanan Pengujian Kendaraan Bermotor oleh Birokrat Dinas Perhubungan Berbasis Nilai Keadilan}

Rekonstruksi pelayanan pengujian kendaraan bermotor oleh birokrat Dinas Perhubungan berbasis nilai keadilan, dilakukan dengan cara sebagai berikut:

a. Penggunaan SIMPengujian Kendaraan Bermotor

Konsep baru dalam Pengujian Kendaraan Bermotor dapat digunakan Sistem Informasi Manajemen Pengujian Kendaraan Bermotor (SIM PKB). Sistem Informasi Manajemen Pengujian Kendaraan Bermotor 
adalah sebuah aplikasi software yang berbasiskan pada sebuah Sistem Informasi Manajemen sehingga mempunyai fungsi-fungsi yang lengkap dalam implementasinya. Tujuan utama dari dikembangkannya SIM-PKB ini adalah untuk memberikan layanan yang lebih cepat, transparan dan aurat di sisi pelayanan publik serta memberikan kemudahan dalam proses penyelenggaraan sistem pengujan kendaraan bermotor.

b. Swastanisasi Pelaksanaan Pengujian Kendaraan Bermotor

Pelaksanaan kir di negara-negara lain seperti Jepang, Jerman, Amerika Serikat dan negara-negara maju lainnya telah diberlakukan untuk semua jenis kendaraan bermotor dan pengerjaannya dilakukan oleh swasta. Tujuan pembuatan suatu mekanisme pengawasan ini, pada hakikatnya tidak terlepas dari faktorfaktor sebagaiberikut:

a. Keselamatan lalu lintas dan kendaraan itu sendiri

b. Proteksi terhadap lingkungan

c. Penghematan energi (konsumsi bahan bakar)

Sistem pengujian berkala kendaraan bermotor yang diterapkan di negara lain seperti Jerman maupun di negara maju lainnya, dilaksanakan oleh lembagapengujian swasta yang ditunjuk oleh Pemerintah untuk melaksanakanpengujian. Penunjukkan ini merujuk pada beberapa kategori yang harusdipenuhi oleh suatu institusi pengujian, seperti misalnya TUV/ DEKRA (Lembaga Pengujian Teknik).

Berdasarkan jenisnya bengkel yang terdapat di Jerman dapat dibagi menjadi dua jenis, yaitu:

1. Bengkel yang bertindak hanya sebagai lembaga perawatan

2. Bengkel yang bertindak sebagai lembaga perawatan dan pengujianberkala kendaraan bermotor.
Klasifikasi bengkel jenis ini sama halnya dengan yang terdapat di Amerika Serikat. Hanya saja di Amerika Serikat, bengkel perawatan dan pengujiandibagi menjadi dua jenis:

a. Bengkel perawatan dan pengujian untuk kelaikkan jalan dan pengujianemisi gas buang kendaraan bermotor: untuk kendaraan umum penumpang dan barang. Umumnya bengkel jenis ini milik perusahaanangkutan yang beroperasi di daerah tersebut.

b. Bengkel untuk perawatan dan pengujian untuk pengawasan emisi gas buang kendaraan bermotor untuk kendaraan pribadi.

Di Amerika Serikat, setiap pemerintah negara bagian (State Government) bertanggung jawab terhadap pelaksanaan program pengujian berkala yangmerupakan salah satu dari butir driving law yang dilakukan di tiap daerahnegara bagian tersebut. Dalam pelaksanaannya setiap negara bagian membentuk suatu departemen DMV (Departement Motor Vehicle) yangmelakukan pengawasan terhadap pengujian berkala dan registrasi bagi setiap kendaraan yang tercatat di daerahnya masing-masing. DMV bekerjasama dengan suatu asosiasi bengkel yang beroperasi di Amerika Serikat, yaitu BAR (Bureau Auto Repair) yang bertanggung jawab terhadap kelangsungan operasional dan standar waktu perbaikan bagi perawatankendaraan yang dilakukan di bengkel.

Di negara Jepang, pelaksanaan pengujian berkala kendaraan bermotor dilakukan oleh bengkel yang diklasifikasikan menjadi 2 meliputi bengke lumum yang sudah disertifikasi (certified shop), dan identified shop yang terdiri dari the first grade identified shop, the second grade identified shop serta identified special 
service shop (bengkel body, peralatan dan lain-lain).Selanjutnya bengkel yang dapat melakukan kir adalah bengkel yang memilikikualifikasi, the first grade identified shop, dan the second grade identifiedshop.

Di Indonesia, baru di DKI Jakarta yang telah melakukan kerjasama dengan swasta yaitu melibatkan PT. Sawu (Suar Adhika Wahana Ujindo). PemprovDKI Jakartamenjalin kemitraan dengan PT. Sawu dalam mengelola UPTPKB Jagakarsa sejak tahun 1996. Dalam pola kemitraan Built Operate \&Transfer (BOT) dengan Pemprov DKI Jakarta, PT.SAWU menyediakan seluruh sarana dan prasarana UPT PKB Jagakarsa, sedangkan Pemprov DKI Jakarta menyediakan petugas dari Dinas terkait yang berwenang dalam pengelolaan PKB.

Jadi pada prinsipnya, di Indonesia belum ada pelaksanaan pengujian berkala yang dilakukan kerjasama dengan bengkel-bengkel umum (authorizedworkshop atau non authorized workshop) milik swasta seperti di negara-negara Jerman, Amerika Serikat, Jepang atau negaranegara maju lainnya. Klasifikasi bengkel umum di Indonesia terdiri dari:

- Bengkel Kelas I Tipe A-B dan C

- Bengkel Kelas II Tipe A-B dan C

- Bengkel Kelas III Tipe A-B dan C

Pengertian bengkel umum dalam hal ini adalah bengkel umum kendaraanbermotor yang berfungsi untuk membetulkan, memperbaiki dan merawatkendaraan bermotor agar tetap memenuhi persyaratan teknis dan laik jalan. Pengklasifikasian bengkel umum dapat diartikan sebagai tingkat pemahaman terhadap persyaratan sistem mutu, mekanik, fasilitas dan peralatan sertamanajemen/tenaga ahli sesuai dengan penilaian yang diterbitkan olehLembaga Sertifikasi c. Efektivitas Pengawasan Pengujian Kendaraan Bermotor

Untuk mengurangi jumlah kecelakaan lalu lintas akibat kendaraan bermotor yang tidak laik jalan, di Negara Jerman dilaksanakan pemisahan antara tindakan pelaksanaan dengan pengawasan.

Pelaksanaan Pengujian Kendaraan Bermotor oleh pihak swasta sedangkan pemerintah hanya sebagai pengawas dengan melibatkan lembaga eksternal untuk membantu pemantauan pelaksanaan Uji Kir. Pemerintah hanya mengawasi akuntabilitas yang dilaksanakan oleh swasta.

Konsep pemisahan antara pelaksanaan dan pengawasan Pengujian Kendaraan Bermotor di Negara Jerman berjalan secara efektif. Langkah pengawasan yang dilakukan dengan memasangkan closed circuit television (CCTV), untuk dapat memantau setiap tahap pelaksanaan Pengujian Kendaraan Bermotor

d. Efisiensi dan Pengalihan sumber bahan bakar sebagai penyebab polusi

Di Negara Singapura telah menetapkan kebijakan di sektor transportasi darat dengan strategi menciptakan penggunaan transportasi umum, mengendalikan penggunaan dan kepemilikan kendaraan pribadi serta pengalihan sumber bahan bakar kendaraan dari minyak ke listrik.

Beberapa studi epidemiologi dapat menyimpulkan adanya hubungan yang erat antara tingkat pencemaran udara perkotaan dengan angka kejadian (prevalensi) penyakit pernapasan. Kendaraan bermotor akan mengeluarkan berbagai gas jenis maupun partikulat yang terdiri dari berbagai senyawa organik dan anorganik dengan berat molekul yang besar yang dapat langsung terhirup melalui hidung dan mempengaruhi 
masyarakat di jalan raya dan sekitarnya

e. Pembatasan usia kendaraan bermotor.

Di negara Singapura telah ditetapkan bahwa maksimal usia kendaraan yang diperbolehkan untuk beroperasi di jalan raya maksimal adalah 5 (lima) tahun, sedangkan apabila melebihi usia tersebut maka kendaraan tersebut harus sudah di besi tuakan. Hal ini dimaksudkan bahwa dengan usia kendaraan dibawah 5 (lima) tahun kendaraan tersebut secara teknis masih laik jalan, sehingga tidak menimbulkan resiko terhadap terjadinya kecelakaan lalu lintas maupun pencemaran lingkungan

f. Penetapan pajak Progresif kendaraan berdasarkan usia kendaraan

Pemerintah Daerah harus menciptakan regulasi tentang Pengujian Kendaraan bermotor yang membedakan besaran tarif retribusi berdasarkan usia kendaraan. Makin tua umur kendaraan maka biaya retribusi yang dikeluarkan makin mahal. Misalkan, untuk kendaraan yang berumur satu tahun sebesar Rp.25.000,- (Dua puluh lima ribu rupiah ), maka untuk pertambahan usia kendaraan tiaptiap tahunnya dilipatkan dua. Jadi untuk kendaraan berusia 2 (dua) tahun, besaran retribusinya menjadi Rp.50.000,- (lima puluh ribu rupiah).

\section{KESIMPULAN}

a. Faktor-faktor yang berpengaruh terhadap regulasi pemerintah daerah tentang pengujian kendaraan bermotor yang belum berbasis nilai keadilan terdapat adanya Retribusi dan regulasi yang terdapat di Peraturan Daerah Dinas Perhubungan ditingkat Jawa Tengah.

b. Pelaksanaan Birokrasi dalam pengujian Kendaraan Bermotor pada Dinas Perhubungan belum berdasarkan nilai keadilan dikarenakan adanya Problem Statement yang terjadi dalam kaitannya dengan pelayanan dan pengujian kelaikan kendaraan bermotor tidak hanya menyangkut prosedur pelayanan.

c. Rekontruksi Birokrasi yang harus dilakukan oleh Dinas Perhubungan diukur melalui beberapa indikator diantaranya melalui indikator kinerja dalam manajemen pelayanan Publik.

\section{E. SARAN}

Untuk melakukan Rekontruksi Birokrasi, Penulis menyampaikan Teori Hukum Progresif yang berkeadilan, dengan langkah-langkah yang ditempuh melalui Penggunaan SIMPKB, Swastanisasi Pengujian Kendaraan Bermotor, Pengefektifan Pengawasan, Efisiensi dan pengalihan sumber bahan bakar minyak, pembatasan usia kendaraan dan penetapan pajak progresif kendaraan.

\section{DAFTAR PUSTAKA}

Bernard Arief Sidharta, Disiplin Hukum tentang Hubungan antara Ilmu Hukum, Teori Hukum dan Filsafat Hukum, Makalah, disajikan dalam Rapat Tahunan Komisi Disiplin IImu Hukum, Jakarta, 11-13 Februari 2001

Mohammad ZainBadudu, Kamus Umum Bahasa Indonesia, Jakarta: Pustaka Sinar Harapan,1996

Peter Mahmud Marzuki, Penelitian Hukum, Jakarta: Kencana Prenada Media Grup, 2009

Soetandyo Wignjosoebroto, Hukum, Paradigma, Metode dan Dinamika Masalahnya, Jakarta: Lembaga Studi dan Advokasi Masyarakat, 2002

Soetandyo Wignyosoebroto dalam Otje Salman dan Athon F. Susanto, Teori Hukum: Mengingat, Mengumpulkan dan Membuka Kembali, Bandung: Refika Aditama, 2010

Sugondo BK, Media KORPRI, Edisi Desember 2012 